\title{
Increasing the Indonesia's Tourism Sector to be more Competitively
}

\author{
Sharon Oen - 130218044 - A
}

Currently, Indonesia's tourism sector still supports being a major foreign exchange earner which has a direct impact on society. With the interaction of the community in tourism activities, a large country and the hope of Indonesia can cover the deficit of the transactions carried out, increase employment and help mobilize Micro, Small and Medium Enterprises (MSMEs). The tourism sector has a direct impact on the domestic economy which increases the flow of capital to Indonesia. Not only that, the tourism sector will also indirectly have an impact on the domestic economy, namely the development of the tourism sector is expected to be able to absorb labor so as to increase economic growth.

As we know, Indonesia has many tourist destinations that are no less interesting, such as Borobudur Temple, Mount Bromo, Lake Toba, Raja Ampat, Labuan Bajo and many others. With that, the Indonesian government is trying to increase the number of visitors from abroad by using visas for 169 countries, accelerating the development of transportation infrastructure so that access to tourist destinations can be done easily and making the image of tourism known as Wonderful Indonesia. However, Indonesia still faces problems in the development of the tourism sector. The problem is that the target number of visitors tends to be difficult to achieve due to various factors, such as volcanic eruptions, natural disasters such as tsunamis and earthquakes and others.

Other problems, such as the low level of competitiveness in Indonesia, have contributed to the tourism sector for Gross Domestic Product (GDP) as well as foreign exchange earnings that are still lagging behind other countries such as Singapore, Thailand and Malaysia. It is said to be left behind due to health and hygiene problems, information and communication facts and tourism service infrastructure. In addition, institutional factors, especially in the regions, factors that are prone to crime and dishonesty of the public in transactions and low public awareness. This makes it difficult for Indonesia to become a shopping paradise for tourists in the tourism industry. Not only that, the development of the tourism sector in Indonesia is hampered due to promotional activities that attract tourists and lack of attention to the development of tourist destinations which causes the tourism sector to be not yet optimal. The high cost of domestic flight tickets which are more expensive than 
international flight tickets to tourist destinations is hampered because it makes domestic tourists think twice about visiting other tourist destinations that must be reached by plane.

According to Crouch \& Ritchie (1999) adapting from Michael Porter's model, the attractiveness of tourist destinations is influenced by 4 components, namely (1) core resources \& attractors; (2) supporting factors \& resources; (3) destination management and (4) qualifying determinants (OCED, 1999)

Table 1.1

\section{Destination Attraction}

\begin{tabular}{|l|l|}
\hline \multicolumn{1}{|c|}{ Core Resources \& Attractors } & \multicolumn{1}{c|}{ Supporting Factors \& Resources } \\
\hline 1. Physiography & 1. Infrastructure \\
2. Culture and History & 2. Accessibility \\
3. Market Ties & 3. Facilitating Resources \\
4. Mixed of Activities & 4. Hospitality \\
5. Special Events & 5. Enterprise \\
6. Entertainment & \\
7. Superstructure & \\
\hline \multicolumn{1}{|c|}{ Destination Management } & Qualifying Determinants \\
\hline $\begin{array}{l}\text { 1. Resource Stewardship } \\
\text { 2. Marketing } \\
\text { 3. Finance \& Venture Capital } \\
\text { 4. Organization } \\
\text { 5. Human Resource Development } \\
\text { 6. Information / research } \\
\text { 7. Quality of Service } \\
\text { 8. Visitor Management }\end{array}$ & 2. Interdependence \\
\hline
\end{tabular}

Based on table 1.1, it can be seen that these components have several important aspects for foreign tourists visiting destinations. However, this discussion focuses more on 4 aspects, namely mix of activities, facilitator resources, organization and location. 
Indonesia has experienced a positive shift in 2017 and 2019 due to reduced travel constraints and travel costs as well as the emergence of new tourism activities and international events such as sports tours, fashion, music and cultural shows. Therefore, Indonesia actually has the potential for natural and cultural resources that have a major impact in increasing tourism but the weaknesses lie in the quality of baths, tourism information, destination development, security and cleanliness issues and inadequate tourism service infrastructure. In this regard, it is evident that the Indonesian tourism sector has several advantages, one of which is that the price is more competitive than in Singapore, Malaysia and Thailand. However, there is a weakness in this, namely the limited funds for carrying out promotional activities so that competitive prices are not conveyed to foreign tourists. For example the "Pesona Indonesia" program, which actually many tourists know about it, but the program is not encouraged because there has not been any promotion abroad so that the achievement of tourism indicators is not maximized where the number of foreign tourist visitors is only $12,948,000$ people with a total income of approximately $12,530.8$ million US dollars. or the average income per visit was only 967.8 US dollars in 2019 alone. At present and for the future, the tourism sector is expected to reduce the current account deficit with a target of contributing US $\$ 17.6$ billion in foreign exchange and foreign tourist arrivals of 18 million people in 2019. However, reality says differently, until September 1, 2019 it only reached 9.31. million foreign tourists even though Indonesia's tourism competitiveness has increased to 40 out of 140 countries. This is because in terms of competitiveness, Indonesia's best value lies in terms of price and the lowest value lies in environmental sustainability.

In realizing that Indonesia is superior in tourism destinations, 6 programs are carried out, namely (1) developing destinations; (2) increase competitiveness; (3) increasing the diversity of tourism; (4) increasing tourism integration; (5) strengthening as the main goal of Asia; and the last (6) reinforces it as the world's main goal. Indonesia is actually very rich in natural tourism so that it can be an attraction for tourists who will come, but the time for tourist visits cannot be long because the natural beauty has not been supported by special shows from the creative industry sector such as fine arts, handicrafts and culinary. For example, the blue fire phenomenon in the Crater of Mount Ijen, which is still a mainstay for tourists in Banyuwangi Regency and the Kemiren Traditional Village, which provides traditional cultural and culinary tours. This results in attracting 1,000 tourists a day. So it can be concluded that the relationship between the tourism sector and the creative industry is able 
to drive the economy in Banyuwangi Regency, East Java province. The existence of the tourism sector and the creative industry cannot be denied for people who currently make traveling a necessity. In a sense, the holiday segment continues to develop along with changes in people's lifestyles where vacation is a necessity.

The encouragement of the village economy is also caused by the implementation of tourism development. It increases income, reduces unemployment and suppresses urbanization. For example, a number of villages in the Special Region of Yogyakarta have developed tourism, including Pentingsari Hamlet, Umbulharjo Village, Cangkringan District, Sleman Regency and Bejiharjo Village, Karangmojo District, Gunung Kidul Regency. By developing this tourism, the villagers earn an additional income of between Rp. 1 million and Rp. 2 million per month. In addition, the attractiveness of the Special Region of Yogyakarta is still high due to the support of the people themselves who are still innovative, creative and empathetic, such as the regular Jogja Biennale which is held annually and followed by other communities. Another example occurs at Borobudur Temple where there is a Borobudur Marathon which is held every year and there is a Village Economic Center, bicycle rental facilities and Hotel Manohara. However, it is difficult to achieve the target of foreign tourists due to the absence of a routine schedule and inadequate infrastructure and facilities.

Government efforts to prioritize tourism development must be paid close attention to prevent over tourism as a result of tourism exploitation which can worsen the carrying capacity of the environment, ecology, social and culture. For example in Bali, which is increasingly critical due to the attraction to the tourism business and the scandal of smuggling 41 Komodo dragons from Komodo Island abroad. Another factor that needs to be improved is the unfair price competition between conventional travel agents including illegal practices that are only promoted through social media or the internet to attract potential tourists. Longterm investment must be maintained because it can increase Indonesia's bargaining power in the eyes of all over the world, namely by the existence of the purity of the environment, ecology and local culture.

The tourism market is formed because of the balance between supply and demand. Tourism demand is influenced by the amount of income, the effect of promotions, flight or boat ticket prices, availability of facilities and infrastructure, tourism security activity agenda and others. The tourism market is also experiencing rapid development as a result of changes in people's lifestyles, the emergence of new tourist attractions, the hectic promotion of 
tourism and the rapid development of creative and affordable products. This is almost the same as the view of Crouch \& Ritchie (1999) that the tourism sector is heavily influenced by factors from supply and demand, including neglected factors such as clean toilet, expensive flight tickets, discrimination in the price of admission to tourist objects, including prices by by. Without any efforts to improve and change the competitiveness of Indonesian tourism to be less competitive with other countries that can be said to routinely innovate and develop creativity.

Based on the above discussion, it can be concluded that the tourism sector and the creative industry have had a major impact on the development of the nation's economy, especially tourism. Therefore, it is important to collaborate between the Central and Regional Governments so that the tourism sector can make a positive contribution to regional development, employment, foreign exchange and others while maintaining the preservation of local nature and culture. Tourism development in Indonesia is carried out not only on infrastructure but also on the ecosystem. The key to the success of tourist destinations from various aspects such as culture, creativity and friendliness makes tourist destination communities not only as spectators. Therefore, tourism development is expected to provide economic benefits, protect the environment and empower the community. 